\title{
An audit of a high caloric refeeding regimen used for medically unstable adolescent inpatients with severe restrictive eating disorders
}

\author{
Danielle Hewitt ${ }^{*}$, Gail Anderson ${ }^{1}$, Andrew Kennedy ${ }^{1}$, Linette Gomes ${ }^{1}$, Elizabeth Parker ${ }^{2}$, Christine Wearne ${ }^{3}$, \\ Michael Kohn ${ }^{1}$, Simon Clarke ${ }^{1}$
}

From 2014 ANZAED Conference: Driven Bodies Driven Brains

Fremantle, Australia. 22-23 August 2014

\section{Aim}

To present data on outcomes including weight and BMI gain, length of stay and complications of a high caloric refeeding regimen.

\section{Methods}

A retrospective audit of 98 consecutive admissions over 36 months of medically unstable patients (Defined as bradycardic HR $\leq 50$ ), who had a BMI of $\leq 18.5 \mathrm{~kg} / \mathrm{m} 2$. Patients were prescribed a regimen of nasogastric feeds and oral diet graded up from $2400 \mathrm{Kcal} /$ day to over $4000 \mathrm{Kcal} /$ day. Prophylactic oral phosphate was routinely prescribed.

\section{Results}

Median age 16.6 years (range: 14.7 - 19.9), median BMI $16.2 \mathrm{~kg} / \mathrm{m} 2(12.4-18.5)$ on admission. Median weight gain in first week $4.0 \mathrm{~kg}(1.2-6.9)$, median total weight gain $7.8 \mathrm{~kg}$ (3.3 - 18.3). Median BMI on discharge $19.1 \mathrm{~kg} / \mathrm{m} 2$ (16.4 - 21.0). Median length of stay 24.4 days (6.0 82.3 days). No admissions resulted in refeeding syndrome. Peripheral oedema and/or mild electrolyte abnormality occurred in $20.4 \%$ of admissions.

\section{Conclusion}

It is possible to use a refeeding regimen that is higher in total caloric intake than currently recommended approaches, including NICE guidelines. With specialist medical and nursing care, relatively rapid weight gain and clinical stabilisation occurs with minimal complications. A prospective comparison between centres or a randomised

\footnotetext{
* Correspondence: hewitt.danielle@gmail.com

${ }^{1}$ Department of Adolescent Medicine, Westmead Hospital, Sydney, Australia Full list of author information is available at the end of the article
}

controlled trial would contribute further to the evidence in this field.

This abstract was presented in the Service Initiatives: Child and Adolescent Refeeding and FBT stream of the 2014 ANZAED Conference.

\section{Authors' details}

${ }^{1}$ Department of Adolescent Medicine, Westmead Hospital, Sydney, Australia. 2Department of Dietetics and Nutrition, Westmead Hospital, Sydney,

Australia. ${ }^{3}$ Department of Medical Psychology, Westmead Hospital, Sydney, Australia.

Published: 24 November 2014

doi:10.1186/2050-2974-2-S1-020

Cite this article as: Hewitt et al:: An audit of a high caloric refeeding regimen used for medically unstable adolescent inpatients with severe restrictive eating disorders. Journal of Eating Disorders 2014 2(Suppl 1):020.

Submit your next manuscript to BioMed Central and take full advantage of:

- Convenient online submission

- Thorough peer review

- No space constraints or color figure charges

- Immediate publication on acceptance

- Inclusion in PubMed, CAS, Scopus and Google Scholar

- Research which is freely available for redistribution

Submit your manuscript at www.biomedcentral.com/submit
() Biomed Central 